\title{
Oviposition deterrent and ovicidal properties of Calotropis gigantea (L.) leaf extract to Paraeucosmetus pallicornis (Dallas) in rice
}

\author{
Sylvia Sjam ${ }^{1 *}$, Ade Rosmana ${ }^{1}$, Vien Sartika Dewi ${ }^{1}$, Dian Ekawati Sari², \\ Untung Surapati Tresnaputra ${ }^{1}$, Asti Herawati ${ }^{1}$ \\ ${ }^{1}$ Department of Plant Pest and Disease, Hasanuddin University, Makassar, 90245, Indonesia \\ ${ }^{2}$ High School of Agriculture, Sinjai, 92612, Indonesia
}

Vol. 57, No. 3: 243-247, 2017

DOI: 10.1515/jppr-2017-0034

Received: August 19, 2016 Accepted: August 17, 2017

*Corresponding address: sylviasjam@unhas.ac.id

\begin{abstract}
Paraeucosmetus pallicornis (Dallas) is a new pest in Indonesia which decreases rice production and quality. This pest causes the grains to become flat, hollow, brownish, break easily when milled, and bitter. This research represents the first study on Calotropis gigantea extract as an oviposition deterrent and ovicide against $P$. pallicornis. The study was conducted under laboratory conditions using four extract concentrations i.e. 0.5, 1.0, 1.5 and $2.0 \%$. The oviposition deterrent effect was determined by counting the number of eggs laid and hatched. Percent reproductive control (PRC) and ovicidal activity was calculated using Tennyson's formula. Results indicated that all concentrations of C. gigantea leaf extract reduced the number of eggs laid and hatched. The PRC also showed a gradual reduction of oviposition of the P. pallicornis and the ovicidal activity ranged between 86.5 and $100 \%$. The extract concentration which showed the highest potential as an oviposition deterrent and ovicide against $P$. pallicornis was in the range of $1.0-2.0 \%$. The overall results indicated that C. gigantea leaf extract has the potential to be used as an oviposition deterrent and ovicide against $P$. pallicornis.
\end{abstract}

Key words: Calotropis gigantea, leaf extract, ovicidal, oviposition, Paraeucosmetus pallicornis

\section{Introduction}

Paraeucosmetus pallicornis (Dallas) (Hemiptera: Lygaeidae) also known as black ladybug, is a new rice pest in Indonesia and notably in Sulawesi. This pest infests rice from the seedling stage until harvest. Rice grains from plants which have been attacked by this pest become flat, hollow, brownish, crumbly, and bitter. It also causes chlorosis symptoms or causes the plants' leaves to dry (Rosmana et al. 2014). Nowadays, this pest has also been found on newly harvested grain in storage.

Presently, the only way to control P. pallicornis is through the use of synthetic pesticides. The use of synthetic pesticides among farmers tends to be excessive and in the long run can have negative impacts such as environmental pollution, pest resistance, secondary pest population explosion, as well as on human health. Therefore, alternative and environmentally friendly methods are needed to control P. pallicornis such as using plant extracts.

Calotropis gigantea (L.) is a wasteland weed, better known as milkweed. This weed is widely distributed in sub-tropical and tropical countries (Khondkar et al. 2010) which include India, Indonesia, Malaysia, Philippines, Thailand, Sri Lanka and China (Kumar 2010). Calotropis gigantea has been reported for its anti-Candida, cytotoxic, antipyretic, and wound healing activities. Recently, another species of genus Calotropis (C. procera) has also been shown to be a potential biological control of some pests (Bakavathiappan et al. 2015). Calotropis gigantea and 
C. procera are reported to have similar pharmacological characteristics (Krishnan 2010).

Plant extracts have been reported to be effective in controlling pests because they contain secondary metabolites that can have toxic effects, be feeding deterrents, and growth inhibitors. In addition, secondary metabolites from plant extracts have also been found to exhibit repellent, ovicidal, larvicidal, and sterility properties on pests (Islam 2010). Calotropis gigantea has also been reported to contain toxins such as cardenolides, cardiac glycosides, flavonoids, and other cytotoxins effective against pests (Prabhu et al. 2012). The effectiveness of C. gigantea extract in controlling $P$. pallicornis was studied by observing its ovicidal effects on the number of eggs laid and hatched. Therefore, the objective of this research was to analyse the effects of C. gigantea leaves on P. pallicornis.

\section{Materials and Methods}

\section{Preparation of extracts and their concentrations}

Leaves of $C$. gigantea were collected from areas in and around Takalar Regency of South Sulawesi, Indonesia and shade-dried for 2-3 days, macerated with methanol solvent for 7 days and filtered through filter paper. The solvent was removed by evaporation on a water bath for 6-8 h to obtain crude extract in the form of paste. It was then placed in a reagent bottle, and stored in the refrigerator as a stock solution prior to its use. Four different concentrations: $0.5,1.0,1.5$ and 2.0\% of the extract were prepared by diluting the stock solution with acetone.

\section{Rearing the Paraeucosmetus pallicornis}

Paraeucosmetus pallicornis were collected from rice plants in Bantaeng Regency of South Sulawesi for the insects to be raised in a laboratory. The insects were maintained in rice plants and reared in the insectarium at laboratory under controlled conditions of $26 \pm 1^{\circ} \mathrm{C}, 70 \pm 5 \%$ relative humidity $(\mathrm{RH})$. Male and female adult insects were selected from a colony reared in the laboratory and placed in a cage with rice plants. The adults were allowed to grow until the F1 generation for testing.

\section{Oviposition deterrent}

The different crude extracts were sprayed on rice plants growing in cages. Pairs of new adults were introduced for four replication in each concentration in different cages containing rice plants. The impact of the oviposition deterrent under study is indicated by the number of eggs laid. Eggs were observed on separate Petri dishes until hatching. The percent reproductive control (PRC) was calculated following Rizvi et al. (1980):

PRC $=\frac{\begin{array}{c}\text { The number of eggs } \\ \text { laid by control }\end{array}-\begin{array}{c}\text { The number of eggs } \\ \text { laid by treated }\end{array}}{\text { The number of eggs laid by control }} \times 100$.

\section{Ovicidal effect}

The egg mass was collected from the eggs laid by female in the laboratory rearing and observed for ovicidal activity. The ovicidal activity of plant extracts for each was tested on the $P$. palliornis eggs with the residual method. The extracts were transferred to Petri dishes $(0.4 \mathrm{ml})$ and 10 eggs/replication (40 eggs) were then placed on other Petri dishes. The numbers of eggs hatched in control and treatments were recorded. The percentage of ovicidal activity (POA) was calculated using Tennyson's formula as follows:

$$
\text { POA }=\frac{\begin{array}{l}
\text { The number of eggs } \\
\text { hatched by control }
\end{array}-\begin{array}{l}
\text { The number of eggs } \\
\text { hatched by treated }
\end{array}}{\text { The number of eggs hatched by control }} \times 100 \text {. }
$$

The ovicidal effect of C. gigantea extract is determined by grouping the results of calculation into the following categories (Arivoli et al. 2013):

- no ovicidal activity;

+ ovicidal activity below $25 \%$ (low);

++ ovicidal activity between $25-50 \%$ (middle);

+++ ovicidal activity between $50-75 \%$ (high);

++++ ovicidal activity above $75 \%$ (very high).

The percentage of eggs hatched was calculated by formula:

$$
\text { Eggs hatched }=\frac{\text { The number of eggs hatched }}{\text { The number of eggs laid }} \times 100 \text {. }
$$

\section{Statistical analysis}

Statistical analysis was carried out for the number of eggs laid and hatched using the statistical software SPSS for Windows version 10.0.1 to calculate the means, standard errors and standard deviations. Oneway analysis of variance (ANNOVA) was applied to the data to determine differences. To check significant differences between the levels of the mean factor with Tukey's multiple comparison test were $\alpha=0.05$.

\section{Results and Discussion}

The results of the study indicated that all of the C. gigantea leaf extracts acted as oviposition deterrents against $P$. pallicornis by reducing the number of eggs laid and their hatching compared to the control and 


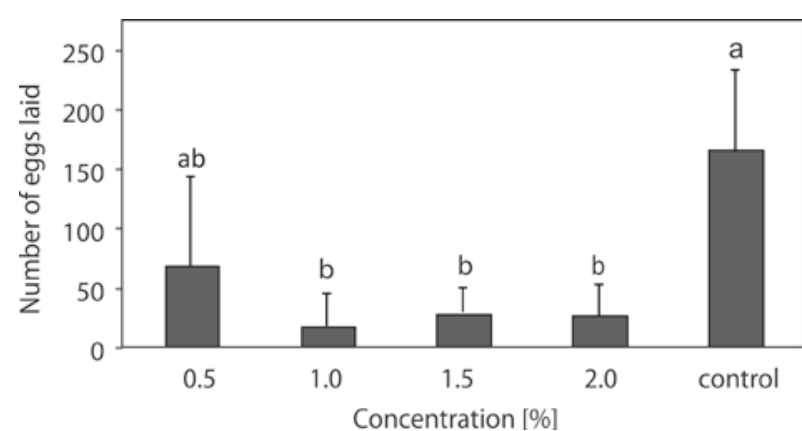

Fig. 1. The impact of different concentrations of Calotropis gigantea leaf extract on the number of Paraeucosmetus pallicornis eggs laid. Means with the same letter are not significointly different according to Tukey's multiple range test at $p=0.05$

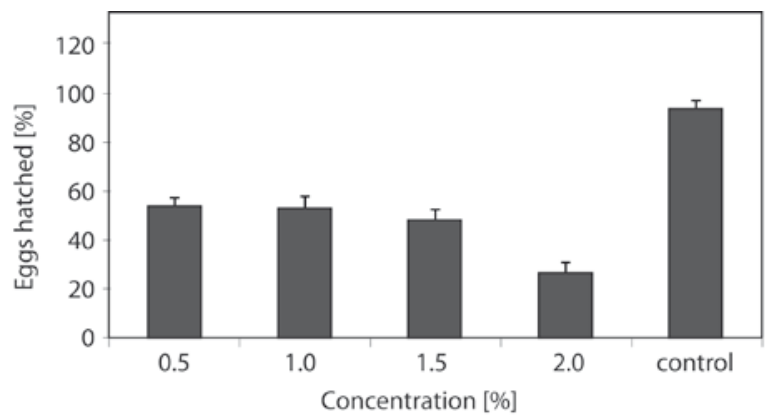

Fig. 3. Percent of eggs hatched of each concentration of Calotropis gigantea leaf extract

significantly different (Figs. 1-3). All exhibited high oviposition deterrent effects against $P$. pallicornis. The lowest number of eggs laid at 1.0, 1.5, and 2.0\% respectively. The percent reproductive control (PRC) also showed a gradual reduction in oviposition of the P. pallicornis. The highest values of $1.0,1.5$ and $2.0 \%$ concentrations of C. gigantea were $84.15-90.2 \%$, respectively. For $0.5 \%$ concentrations it was only $58.8 \%$ (Fig. 4). All these concentrations showed positive values, so that it can be concluded that $C$. gigantea is an effective oviposition deterrent against $P$. pallicornis. Values of PRC indicated that the greater the PRC value the less the number of eggs laid and eggs hatched.

Calotropis gigantea leaf extract with the highest ovicidal activity of $100 \%$ was seen at $1.0,1.5$ and $2.0 \%$ concentrations, while with $0.5 \%$ concentration it only reached $86.51 \%$ (very high ovicidal activity; Table 1 ). Data indicates that $C$. gigantea leaf extract has potential to be ovicidal against $P$. pallicornis with an effectivity greater above $75 \%$. Calotropis gigantea leaf extract can be an oviposition deterrent and have an ovicidal effect because it contains some inhibitory compounds i.e. phenolic, flavonoids, alkaloids, tannin, saponin, glycosides, steroid and phytosterol (Kumar et al. 2012; Gouri et al. 2014). Calotropis gigantea has ovicidal effects against Helicoverpa armigera eggs and inhibits egg hatching up to $100 \%$ (Prabhu 2012). A chloroform extract of C. gigantea exhibited the best larvicidal activity

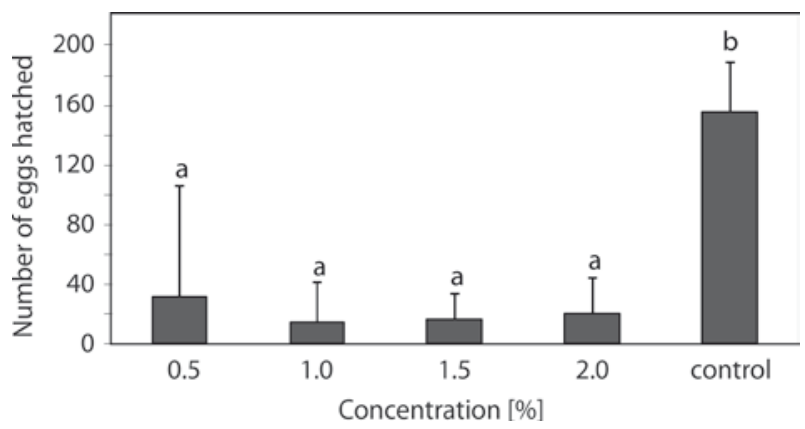

Fig. 2. The impact of different concentrations of Calotropis gigantea leaf extract on the number of Paraeucosmetus pallicornis eggs hatched. Means with the same letter are not significointly different according to Tukey's multiple range test at $p=0.05$

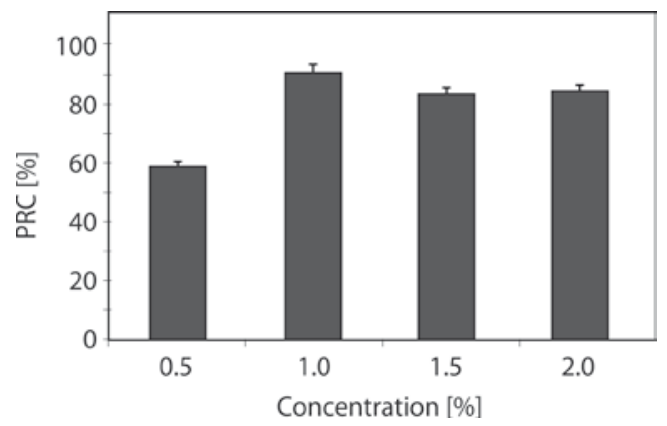

Fig. 4. Percent Reproductive Control (PRC) of Calotropis gigantea leaf extract at different concentrations

and was the best anti-feedant against the Spodoptera litura (Bakavathiappan 2012). The activity was directly proportional to the concentration of the extract.

Inhibition of egg hatching was influenced by a flavanoid compound. It inhibits the activity of some enzymes i.e. protease, lipase and chitinase (Botura et al. 2013). Calotropis gigantea contains $\alpha$-amyrin acetate that can cause the ovicidal effect on insects (Kappusamy and Murugan 2012). In addition, C. gigantea also contains saponins steroidal compounds in large quantities (Seniya et al. 2011) which is probably caused by egg hatching's inhibition. In general, plant extract steroid compounds will inhibit protein by blocking sterol carrier protein, a protein needed for insects' development (Kumar et al. 2012). Protein is needed to produce an adult female insect juvenile hormone which is used for the development and maturation of ovarian eggs (Genc 2006). As a consequence of the lack of protein insect morphology becomes abnormal. Morphologically abnormal eggs are found in P. pallicornis insects treated with $C$. gigantea leaf extracts.

For the control, normal eggs of $P$. pallicornis are egg-shaped, elongated, oval and slippery (Fig. 5A). Abnormal P. pallicornis eggs resulting from treatment are torn, crushed, brown, flat, and hollow (Fig. 5B). Such morphological changes of eggs can be caused by saponin compounds of $C$. gigantea. They may lead to the destruction of the eggs and cause the egg shell 
Table 1. Ovicidal effect of Calotropis gigantea leaf extract against Paraeucosmetus pallicornis

\begin{tabular}{lccc}
\hline Plant extract & $\begin{array}{c}\text { Concentration } \\
{[\%]}\end{array}$ & $\begin{array}{c}\text { Ovicidal } \\
{[\%]}\end{array}$ & $\begin{array}{c}\text { Ovicidal } \\
\text { effect }\end{array}$ \\
\hline \multirow{3}{*}{ C. gigantea } & 2.0 & 100 & ++++ \\
& 1.5 & 100 & ++++ \\
& 1.0 & 100 & ++++ \\
& 0.5 & 86.51 & ++++ \\
\hline
\end{tabular}

++++ Ovicidal activity above $75 \%$

chorion to be torn or destroyed. Saponin can also degrade a protein which is one constituent of egg chorion. It causes destabilization (unstable) and increases membrane permeability (Francis et al. 2002). Saponins also act as an astringent since they cause biological tissue to contract or shrink. Compounds such as soap due to saponins, can act as surface-active agents, which reduce the surface tension and damage the cell wall. As a result the cell membranes have no protector and there is a loss of cell membrane permeability (Astuthi et al. 2011).

Calotropis gigantea also contains steroid compounds ( $\beta$-sitosterolacetate) that can cause growth inhibition (anti-juvenile hormone), by suppressing embryonic eggs' development (Islam et al. 2012). Steroids of the class terpenoida affect insects'growth and development (Manitto 1981). In general, steroid compounds of plant extracts will inhibit protein by blocking the sterol carrier protein (Kumar et al. 2012), leading to abnormal insect morphology. In 1970 it was found that steroids also cause abnormal development of the oocyte by blocking the oocyte reducing egg yolk contents (Veeravel and Manikantan 2007).

Morphologically abnormal eggs and ovicidal effects could also be caused by the penetration of chemical compounds into the chorion of eggs. Similar results were reported that the surfaces of eggs treated with mahlab Prunus mahaleb L. may allow the chemicals to penetrate the chorion of eggs through the micropyle. This would result in the mortality of the embryo or affect the respiratory activity by the formation of a granular protrusion on the chorionic surface that blocks aeropyles and causes respiratory impairments, probably affect metabolism and consequently other systems that would lead to egg mortality (Hala et al. 2016).

Other compounds contained by C. gigantea include asmudarin, anthocyanins, calactin, calotropin, 18, 20epoxy-cardenolides, non-protein amino acid, protease
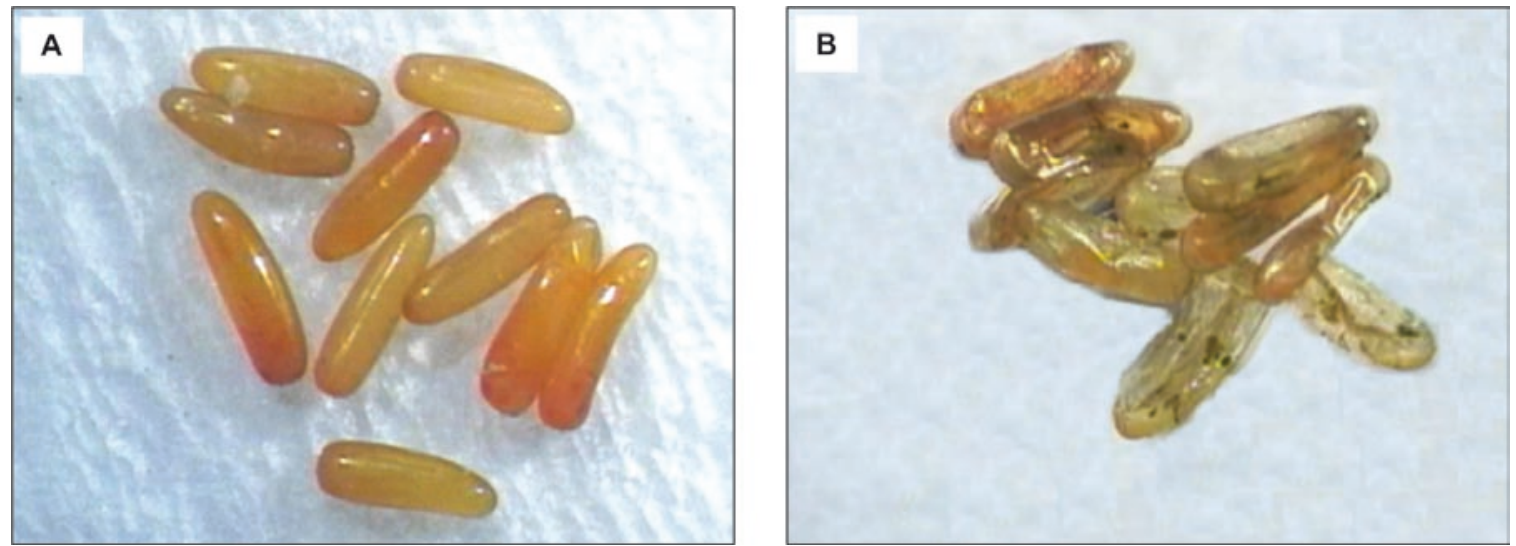

Fig. 5. Eggs of Paraeucosmetus pallicornis: untreated (A) and treated with Calotropis gigantea leaf extract (B)
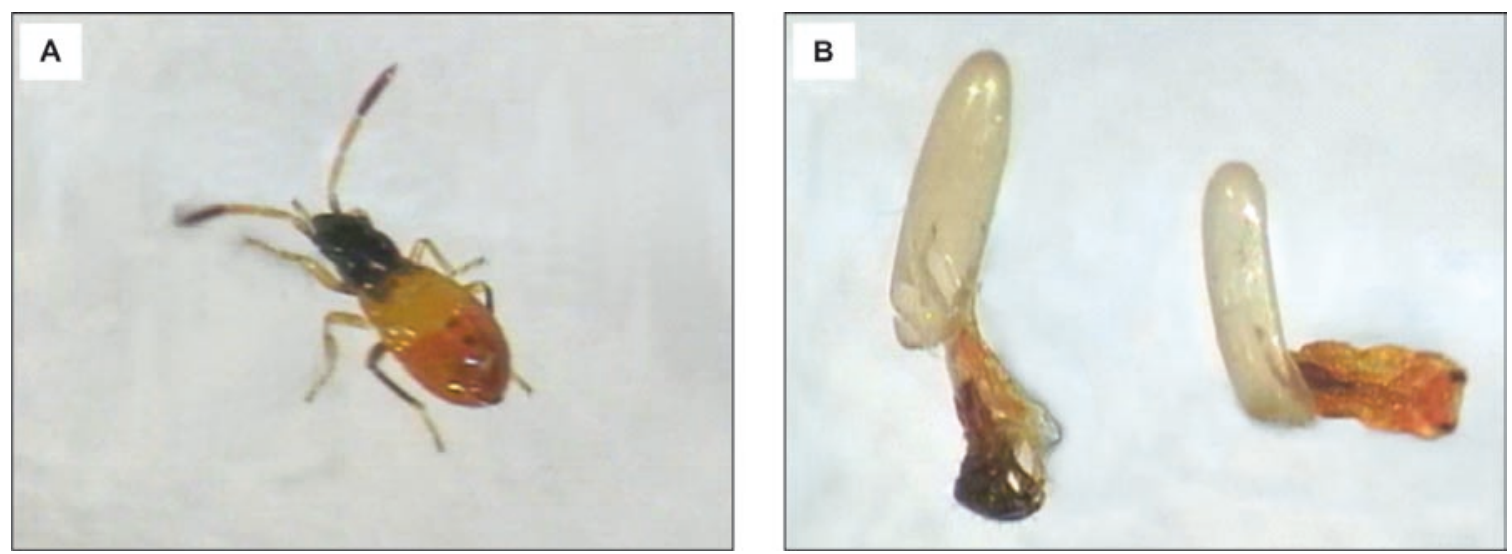

Fig. 6. Nymphs of Paraeucosmetus pallicornis: untreated (A) and treated with Calotropis gigantea leaf extract (B) 
inhibitor, a-amylase inhibitor constitutive, and lectins (David et al. 2011). Protease inhibitors found in C. gigantea can easily affect the development of nymphs. Nymphs hatched after being treated by the extract will become abnormal (Fig. 6). Steroid compounds which can affect the development of insects by inhibiting the growth hormone also cause abnormality in nymphs.

Therefore, research showed that C. gigantea as an ovipositional detterent and ovicide that could be used for the management of pests especially P. pallicornis.

\section{Conclusions}

The leaves of C. gigantea can potentially act as an oviposition deterrent and ovicide against $P$. pallicornis (Dallas) (Hemiptera: Lygaeidae) on rice. Further field studies and research on the preparation of formulas which would enhance potential and stability, toxicity and effects on non-target organisms and the environment are needed to recommend C. gigantea as an eco-friendly botanical that could be used for the management of pests in rice, especially towards $P$. pallicornis, and can replace the harmful use of conventional insecticides.

\section{Acknowledgements}

This research was financed by the Directorate General of Higher Education, Ministry of Research, Technology and Higher Education The Republic of Indonesia. We wish to thank our colleagues from Hasanuddin University, Department of Plant Protection who have provided insight and assisted the authors in completing this research.

\section{References}

Arivoli S., Tennyson S. 2013. Ovicidal activity of plant extract against Spodoptera litura (Fab.) (Lepidoptera: Noctuidae). Bulletin of Environment, Pharmacology and Life Sciences 2 (10): 140-145.

Astuthi M.M.M., Sumiartha K., Susila I.W., Wirya G.N.A.S., Sudiarta I.P. 2012. Efikasi minyak atsiri tanaman cengkeh (Syzygium aromaticum (L.) Merr. \& Perry), Pala (Myristica fragrans Houtt), dan Jahe (Zingiber officinale Rosc.) terhadap mortalitas ulat bulu Gempinis dari family Lymantriidae. Journal of Agricultural Sciences and Biotechnology 1 (1): 12-23.

Bakavathiappan G., Baskaran S., Pavaraj M., Jeyaparvathi S. 2012. Effect of Calotropis procera leaf extract on Spodoptera litura (Fab.). Journal of Biopesticides 5 (Suppl. 1):135-138.

Botura M.B., dos Santos J.D.G., da Silva G.D., de Lima H.G., de Oliveira J.V.A., de Almeida M.A.O., Batatinha M.J.M., Branco A. 2013. In vitro ovicidal and larvicidal activity of Agave sisalana Perr. (sisal) on gastrointestinal nematodes of goats. Veterinary Parasitology 192 (1-3): 211-217. DOI: https://doi.org/10.1016/j.vetpar.2012.10.012
David M., Bharath K.R., Bhavani M. 2011. Study of Calotropis gigantea R. Br. extracts on growthand survival dynamics of selected pathogenic microorganisms. International Journal of Biological Engineering 1 (1): 1-5. DOI: 10.5923/ j.ijbe.20110101.01

Francis G., Kerem Z., Makkar H.P.S., Becker K. 2002. The biological action of saponins in animal systems: a review. British Journal of Nutrition 88 (6): 587-605. DOI: 10.1079/ BJN2002725

Genc H. 2006. General principles of insect nutritional ecology. Trakya University Journal of Natural Sciences 7 (1): 53-57.

Gouri K.S., Reddy B.A., Chaitanya B.S., Kumar B.S., Sivaiah C. 2014. Antimicrobial investigation and phytochemical analysis on organic solvent leaf extract of Calotropis gigantea. International Journal of Biological and Pharmaceutical Research 5 (4): 308-312.

Hala M.M., El-Shafiey S. N., Hend M.S. 2016. Chemical constituents and ovicidal effects of mahlab, Prunus mahaleb L. kernels oil on cotton leafworm, Spodoptera littoralis (Boisd.) eggs. Journal of Plant Protection Research 56 (3): 279-290. DOI: https://doi.org/10.1515/jppr-2016-0044

Islam M.M., Ismail H.M., Abu O.M., Abdul A.M., Rowshahul H.M., Rezau K.M. 2012. A terpenoid and a steroid from Calotropis gigantea (L.). Novel Science International Journal of Pharmaceutical Sciences 1 (8): 580-584.

Kapussamy C., Murugan K. 2012. Skin and oviposition deterrent, ovicidal and deleterious delayed mortality effects of a-amyrin acetate against the malarial vector Anopheles stephensi (Diptera: Culicidae). Journal of the Entomological Research Society 14 (3): 39-53.

Khondkar E.K., Khanand A.R., Rahman A.S.M.S. 2010. Larvicidal effect of latex from Calotropis gigantea (L.) W.T. Aiton against the mosquito, Culexquinque fasciatus Say (Diptera: Culicidae). University Journal of Zoology, Rajshahi University 29: $77-80$.

Krishnan Marg 2010. The wealth of India. Raw materials series: A ready reckoner on biodiversity and bioresources of India (A wealth of information on plants, animals and minerals). National Institute of Science Communication and Information Resources. New Delhi, India.

Kumar G., Karthik L., Rao K.V.B., Kirthi A.V., Rahuman A.A. 2012. Larvicidal, repellent and ovicidal activity of Calotropis gigantea against Culex gelidus, Culex tritaeniorhynchus (Diptera: Culicidae). Journal of Agricultural Technology 8 (3): 869-880.

Mannito P. 1981. Biosynthesis of Natural Products. John Willey \& Sons, New York, USA, 548 pp.

Prabhu S., Priyadharshini P., Veeravel R. 2012. Effect of aqueous extracts of different plant parts of milkweed plant (Calotropis gigantea $\mathrm{R}$. Br.) against ovicidal activity on Helicoverpa armigera (Hübner). International Journal of Advanced Life Sciences 2: 39-44.

Rizvi S.J.A., Pandey S.K., Muderjii D., Mathur S.K. 1980. 1,3,7-Trimethylxanthine, a new chemosterilant for stored grain pest, Callosobruchus chinensis L. Zeitschrift für Angewandte Entomologie 90: 378-381. DOI: 10.1111/j.14390418.1980.tb03541.x (in Geman, with English summary)

Rosmana A., Sjam S., Sari D.E., Nurwahidah U., Hakkar A.A., Ala A., Gassing N. 2014. Fungi associated with Paraeucosmetus pallicornis causing apparent symptoms of toxicity in rice grains and rice seedlings. International Journal of Current Microbiology and Applied Sciences 3 (2): 407-414.

Seniya C., Trivedia S.S., Verma S.K. 2011. Antibacterial efficacy and phytochemical analysis of organic solvent extracts of Calotropis gigantea. Journal of Chemical and Pharmaceutical Research 3 (6): 330-336.

Veeravel R., Manikantan R. 2007. Bioefficacy of milk weed plant, Calotropis gigantea extract against Spodoptera litura. Indian Journal of Plant Protection 36 (1): 59-6. 